\title{
Determination of Carbon Oxide in Exhausts of Vehicles by Thermocatalytic Method
}

\author{
E. Abduraxmanov, M. M. Sultanov, G. N. Daminov, S. U. Tillayev \\ Samarkand State University of Republic of Uzbekistan, Samarkand City, Uzbekistan \\ Email: ergash50@yandex.ru
}

Received 5 April 2014; revised 14 May 2014; accepted 27 May 2014

Copyright (C) 2014 by authors and OALib.

This work is licensed under the Creative Commons Attribution International License (CC BY).

http://creativecommons.org/licenses/by/4.0/

(c) () Open Access

\begin{abstract}
Selective methods of thermocatalytic determination of carbon oxide and hydrocarbons in exhaust gases of vehicles are based on measurement of different thermo effects of oxidation of a combustible mixture, obtained from two identical thermosensible elements working at different temperatures are developed. At one temperature there is an oxidation of all analyzed gas mixture, and on another-the mixture without a selectively determined component and by the difference of thermo effects an exact concentration of components was determined.
\end{abstract}

\section{Keywords}

Analytical Chemistry, A Thermocathalytic Method, Sensor, Carbon Oxide, Smoke Gases, Analytical Characteristics of Analyzators

Subject Areas: Analytical Chemistry, Atmospheric Chemistry, Electrochemistry, Environmental Chemistry, Green Chemistry, Thermochemistry

\section{Introduction}

The motor transport has occupied the important and necessary place in uniform transport system [1]-[3]. The amount of automobiles in the world day after day is strongly growing. The automobile burning huge amount of fuel, intensively puts an appreciable harm to environment, mainly polluting the atmosphere by toxic components and simultaneously absorbed a plenty of oxygen. Among exhausts of vehicle required the constant analytical control, is carbon oxide (CO), having brightly expressed cancerogenic and irritating actions [4]. In this connection, the aim of elaboration of new generation of selective thermocatalytic sensor (TCS) and automatic gasanalysators, ensuring selective $\mathrm{CO}$ determination in exhaust gases of auto transport are actual problem.

Selective method of thermocatalytic determination of carbon oxide and hydrocarbons in exhaust gases of vehicles based on measurement of different thermo effects of oxidation of a combustible mixture, obtained from two identical thermosensible elements working at different temperatures are developed. At one temperature there is an oxidation of all analyzed gas mixture, and on another- the mixture without a selectively determined

How to cite this paper: Abduraxmanov, E., Sultanov, M.M., Daminov, G.N. and Tillayev, S.U. (2014) Determination of Carbon Oxide in Exhausts of Vehicles by Thermocatalytic Method. Open Access Library Journal, 1: e406.

http://dx.doi.org/10.4236/oalib.1100406 
component and by the difference of thermo effects an exact concentration of components were determined [5] [6].

\section{Experimental}

With the purpose of elaborated of a selective sensor for $\mathrm{CO}$ determination in exhaust gases of vehicles some particulates of its oxidation on different catalysts were investigated. In experiences oxides of such metals as: Co, $\mathrm{Mn}, \mathrm{V}, \mathrm{Zn}, \mathrm{Cr}, \mathrm{Ni}, \mathrm{Cu}$ and $\mathrm{Bi}$ were used as catalysts. In the result of the carry out experiments the highly effective and selective catalysts were obtained and the conditions of $\mathrm{CO}$ oxidation were optimized. At temperatures $375^{\circ} \mathrm{C}-400^{\circ} \mathrm{C}$ on catalysts $\mathrm{Pt} / \mathrm{Al}_{2} \mathrm{O}_{3}, \mathrm{Pt}-\mathrm{Pd} / \mathrm{Al}_{2} \mathrm{O}_{3}$ and $\mathrm{Pt}-\mathrm{Co}_{3} \mathrm{O}_{4} / \mathrm{Al}_{2} \mathrm{O}_{3}$ the practically complete oxidation of hydrocarbons steams of different nature was achieved.

One of possible receptions of selectivity maintenance thermocatalytic of CO definition is a using of thermosensible elements having a various activity to components of a gas mixture. It is known, that each combustible substance has certain temperature of oxidation by air oxygen. This parameter can be used at ensuring of selectivity of catalytic oxidation of combustible substances on the surface of thermo sensible elements made from catalysts of the same composition. In this connection the method of selectivity esurience of thermocatalytic methods based on using of thermo sensible elements-sensors, containing catalysts on the base Pt, having different oxidation temperatures on their surface are offered. Such method of analytical signal measurement has allowed automatically compensate combustible components of a mixture with low threshold of their ignition and calibration a sensor only by the combustible component with a high threshold of ignition. According to this method the temperature difference on the surface of the catalyst of two identical compositions and structures thermo sensible elements, are achieved by selection of their corresponding feeding current.

The value of the established feeding current of the first element is, that on the surface of it's catalyst a simultaneous oxidation of all combustible components of a mixture (G1, G2, G3) has carried out. As the result a target signal of the first element is proportional to total concentration of all combustible components of a mixture and it the second element is much less than the first. Accordingly the temperature of the second element is much lower, than the first, and on the surface of its catalyst all combustible components of a mixture (G1, G2), except of determined (G3) are oxidized. In the result the target signal of the first element is proportional to the sum concentration of all components G1, G2 and G3. The target signal of the second element is proportional to concentration only G1 and G2, and the difference of both signals will be proportional only to exact concentration of a determined component (G3) in a mixture: $(\mathrm{G} 1+\mathrm{G} 2+\mathrm{G} 3)-(\mathrm{G} 1+\mathrm{G} 2)=\mathrm{G} 3$.

\section{Result and Discussion}

$\mathrm{Pt}-\mathrm{Co}_{3} \mathrm{O}_{4} / \mathrm{Al}_{2} \mathrm{O}_{3}$ was used as the catalyst of a sensor for selective determination of $\mathrm{CO}$ in exhaust gases, where $\mathrm{H}_{2}$ and $\mathrm{CO}$ were simultaneously presence. The results by selection of optimum temperatures for thermo sensible element with the catalyst $\mathrm{Pt}_{-} \mathrm{Co}_{3} \mathrm{O}_{4} / \mathrm{Al}_{2} \mathrm{O}_{3}$ are given in Figure 1 .

It is shown, that the signal of a sensor on $\mathrm{H}_{2}$ has achieved the maximal value ( $31-35 \mathrm{mV}$ ) at a feeding of a sensitive element equal to 1.6 - 1.8 V. At such feeding the sensor signal by $\mathrm{CO}$ was equal to zero, and the optimum value of feeding of a sensitive element was equal to $2.6-2.8 \mathrm{~V}$. At such feeding value on the surface of the catalyst $\mathrm{H}_{2}$ and $\mathrm{CO}$ completely were oxidized. Petrol at a feeding value of sensitive element below $3.6 \mathrm{~V}$ in presence of $\mathrm{Pt}_{2}-\mathrm{Co}_{3} \mathrm{O}_{4} / \mathrm{Al}_{2} \mathrm{O}_{3}$ practically didn't react with air oxygen.

TCS with the catalyst Pt-Co $\mathrm{O}_{4} / \mathrm{Al}_{2} \mathrm{O}_{3}$ at voltage of a feeding of the first and second sensitive elements were equal 1.7 and $2.7 \mathrm{~V}$ accordingly has provided selectivity of $\mathrm{CO}$ determination at presence $\mathrm{H}_{2}$ and petrol steams. Thus, on the first sensitive element $\mathrm{H}_{2}$ was oxidized and on the second- $\mathrm{H}_{2}$ and $\mathrm{CO}$. Petrol steams under these conditions on both sensitive elements are not oxidized. Hence the difference of signals of the first and second elements has corresponded to CO concentration in exhaust gas.

Thus, as the result of the carried out experiments the method of maintenance of selectivity of thermocatalytic determination of separate components of exhaust gases of vehicle was developed that allowed automatically compensate a combustible components of a mixtures with low threshold of ignition and to calibrate a sensor only by combustible component, have a high threshold of ignition.

Using the elaborated catalyst and optimized conditions, made TCS for determination CO (TCS-CO) in exhaust gases.

The results by estimation of graduated characteristics of TCS-CO have shown, that in the investigated interval 
of $\mathrm{CO}$ concentration the dependence of analytical signal of sensor from concentration of determined components were rectilinear (Figure 2).

Selectivity of the developed sensor of CO determination presented in exhaust gases was high enough (Table 1).

Thus, in the result of the carried out experiences selective TCS was elaborated, in ensuring express CO determination in wide interval of its concentrations in exhaust gases. The elaborated sensor by accuracy and reproducibility didn't concede to known analogues saving at this expression, portability, simplicity in manufacturing and operation.

The device for the control of carbon oxide in emissions of vehicles was elaborated and it consists of gas-analysator, filter of gases clearing and power unit. The estimation of metrological characteristics of the elaborated gas-analysator was carried out according to GOST 52033-2003. Gas-analysator was undergone to tests in range of CO concentration $0-10 \mathrm{vol} \%$. Results by determination of range of components of gas mixtures by device "AГ-CO-CH" are presented in Table 2.

It is shown, that the dependence of the signal of the elaborated gas-analysator " $\mathrm{A} \Gamma-\mathrm{CO}-\mathrm{CH}$ " of concentration of determined component has a rectilinear character. In the investigated interval of CO concentrations the Sr value didn’t exceed 0.034 , that testifies about correctness and reproducibility of the developed method.

\section{Conclusions}

In the investigated concentrations of petrol steams interval the error gas-analysators was equaled to $0.02 \%$. The variations of "AГ-CO-CH" indications were equaled to $0.03 \%$ and didn't exceed 0.5 of share of the absolute meaning of limit of an admitted basic error on each of measurement ranges. Thus, the founded values of errors

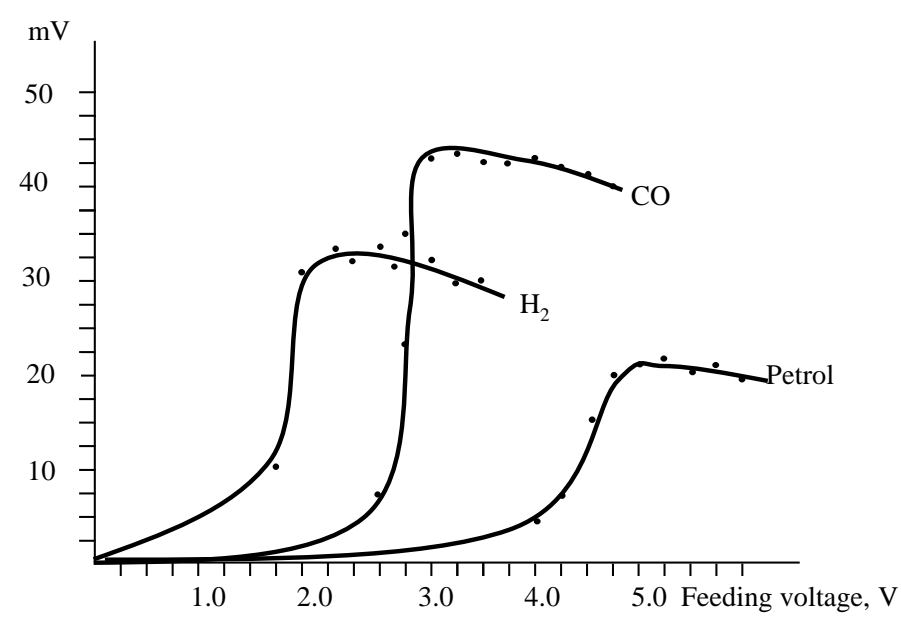

Figure 1. Dependence of TCS signal from the feeding voltage.

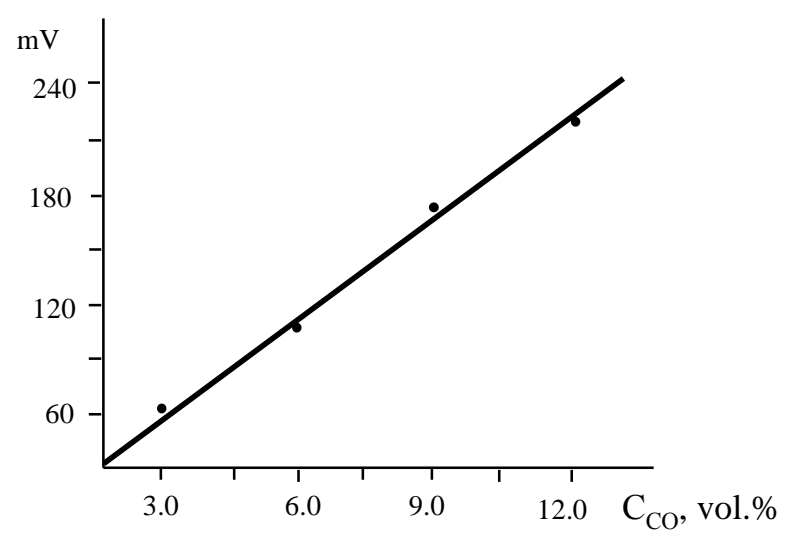

(Correlation coefficient: $\mathrm{y}=\mathrm{a}+\mathrm{bx} . \mathrm{r}_{\mathrm{xy}}=0.9947 ; \mathrm{a}=7.93428 ; \mathrm{b}=19.1806$ )

Figure 2. Graduated characteristics of TCS-CO. 
Table 1. Results by establishment of selectivity TCS-CO at CO determination $(n=5 ; P=0.95)$.

\begin{tabular}{cccc}
\hline Introduced of gaseous mixture, vol\% & \multicolumn{3}{c}{ Finding of carbon oxide, vol\% } \\
\cline { 2 - 4 } $\mathrm{CO}(1.26)+$ air (oct) & $\bar{x} \pm \Delta \mathrm{X}$ & $\mathrm{S}$ & $\mathrm{Sr}^{*} 10^{2}$ \\
\hline $\mathrm{CO}(1.26)+\mathrm{H}_{2}(1.20)+$ air (rest) & $1.26 \pm 0.06$ & 0.05 & 2.9 \\
$\mathrm{CO}(0.44)+\mathrm{H}_{2}(1.20)+$ air (rest) & $1.24 \pm 0.05$ & 0.04 & 2.9 \\
$\mathrm{CO}(1.26)+\mathrm{H}_{2}(2.66)+$ air (rest) & $0.43 \pm 0.01$ & 0.03 & 2.1 \\
$\mathrm{CO}(1.26)+$ petrol $(1.40)+$ air (rest) & $1.22 \pm 0.04$ & 0.03 & 2.4 \\
$\mathrm{CO}(0.44)+$ petrol $(1.40)+$ air (rest) & $1.21 \pm 0.03$ & 0.02 & 2.6 \\
$\mathrm{CO}(1.26)+$ petrol (2.00) + air (rest) & $0.42 \pm 0.01$ & 0.01 & 2.3 \\
\hline
\end{tabular}

Table 2. Results of check measurement of range by the device "АГ-CO-CH" ( $\mathrm{n}=5 ; \mathrm{P}=0.95)$.

\begin{tabular}{ccccc}
\hline \multirow{2}{*}{ № } & Introduced CO, vol\% & \multicolumn{3}{c}{ Finding CO } \\
\cline { 3 - 5 } 1 & 0.25 & $\bar{x} \pm \Delta \mathrm{X}$ & $\mathrm{S}$ & $\mathrm{Sr}^{*} 10^{2}$ \\
\hline 2 & 1.00 & $0.24 \pm 0.01$ & 0.008 & 3.4 \\
3 & 2.00 & $1.02 \pm 0.02$ & 0.017 & 1.6 \\
4 & 4.00 & $1.97 \pm 0.03$ & 0.025 & 1.3 \\
5 & 6.00 & $4.03 \pm 0.03$ & 0.025 & 0.6 \\
7 & 8.00 & $5.96 \pm 0.05$ & 0.042 & 0.7 \\
7
\end{tabular}

and signal variations didn't exceed the allowed limits of the investigated parameters established at normal conditions according to GOST 13320-81.

The check of gas-analysator stability to overloads of concentrations was carried out at CO contents and hydrocarbons in a mixture $12.50 \mathrm{vol} \%$. The experiments have shown that developed gas-analysator "АГ-CO-CH" in the investigated interval of $\mathrm{CO}$ concentration has sustained overloads by concentration. The warming time of the device (no more than 2 mines) and power consumption (no more than $10 \mathrm{~W}$ ) were determined. The tests show, that the contents in a gas mixture $\mathrm{CO}_{2}$ up to $12.5 \mathrm{vol} \%, \mathrm{SO}_{2}-50 \mathrm{mg} / \mathrm{m}^{3}$ and $\mathrm{NO}_{2}-20 \mathrm{mg} / \mathrm{m}^{3}$ didn't show an essential influence on accuracy gas-analysator. Influence of unmeasured components on the total additional error wasn't more than $1.0 \%$. In the result of the carried out investigations it was shown, that the elaborated gasanalysator completely has corresponded to requirements of GOST 52033-2003.

\section{References}

[1] Аксёнов, И.Я. and Аксёнов, В.И. (1986) Транспорт и охрана окружающей среды. Транспорт, 356 с.

[2] Амбарцумян, В.В., Носов, В.Б. аnd Тагасов, В.И. (1999) Экологическая безопасность автомобильного транспорта. ООО Изд. Научтехлитизд, 244 с.

[3] Окружающая среда (1993) Энциклопедический словарь-справочник. Прогресс, 130-136.

[4] Иванов, В.Н., Сторчевус, В.К. аnd Доброхотов, В.С. (1983) Экология и автомобилизация. Киев, Будівельник, 78-96.

[5] Абдурахманов, Э., Даминов, Г. and Султанов, М. (2007) Двухканальный автоматический анализатор для контроля содержания оксида углерода и углеводородов из состава технологических и выхлопных газов. Журн. Химическая промышленность. Санкт-Петербург, 84, 361-366.

[6] Даминов, Г., Абдурахманов, Э., Султанов, М. and Саидова, Ш. (2008) Оптимизация условий и разработка термокаталитического сенсора для мониторинга оксида углерода из состава транспортных выбросов. Журн. Экологические системы и приборы. Москва, 2, 34-36. 